\title{
MODIFIED FEEDING BOTTLE FOR INFANT WITH CLEFT LIP AND PALATE AT THE PERIPHERAL AREA: A CASE REPORT
}

\author{
Fredy Mardiyantoro*, Diwya Nugrahini $H^{* *}$, Lalita El Milla*** \\ *Department of Oral Maxillofacial Surgery, Faculty of Dentistry, Universitas Brawijaya, Malang \\ **Department of Prosthodontics, Faculty of Dentistry, Universitas Brawijaya, Malang \\ ***Department of Dental Material, Faculty of Dentistry, Universitas Brawijaya, Malang \\ Corresponding author: Fredy Mardiyantoro, fredy.fre@ub.ac.id
}

\begin{abstract}
ABSTRAK
Latar belakang: bayi yang lahir dengan celah bibir dan langit-langit, memerlukan asupan makanan untuk meningkatkan nutrisi mereka. Pasien dengan celah bibir dan langit-langit, lidah bayi akan sulit menekan putting susu ke arah palatal. Laporan kasus: bayi perempuan usia 10 hari datang dengan keluhan tidak bisa minum susu dan harus menggunakan sendok untuk minum. Pasien direncanakan operasi tahap 1 setelah berusia 3 bulan dengan berat minimal 10 pounds. Pada pemeriksaan klinis, pasien memiliki celah bibir dan celah langit-langit dengan terpasang nasogastric tube. Pertemuan pertama dilakukan pencetakan dengan menggunakan malam merah yang dipanaskan sehingga dapat dibentuk mengikuti defek pada palatum. Selanjutnya dilakukan pembuatan obturator mengikuti bentuk cetakan. Pembuatan obturator menggunakan impression putty yang digabungkan dengan nipple dari botol susu bayinya. Modifikasi botol susu kemudian dicobakan ke pasien. Kesimpulan: penggunaan putty pada pasien bayi dengan celah palatum dapat berfungsi sebagai obturator yang digabungkan dengan dot, sehingga bayi dapat minum susu dengan optimal sesuai perkembangan rahang. Revisi bottle feeding dilakukan setiap 1-2 minggu hingga tindakan operasi celah dilaksanakan.
\end{abstract}

Kata kunci: cleft palate, feeding bottle, putty material, nutrition

\begin{abstract}
Background: newborn can suck at breast and latch well to get breast milk, but infants born with cleft lip and palate have difficulties to press the nipple by their tongues towards palatal direction. Case report: a 10-day-old female infant came with complaint of not being able to breastfeed from a normal bottle and accordingly need to use spoon for milk feeding. She was planned to perform first step operation at 3 months with minimum 10 pounds of body weight. For nutrient intake, nasogastric tube had been placed on the patient. At the first visit, impression procedure was performed using red wax material that previously warmed thus it can be shaped according to the defect on infant's palate. Subsequently, feeding obturator was fabricated using the resulting cast. Fabrication of feeding obturator used putty impression material combined with feeding bottle nipple. Thereafter, the modified feeding bottle was tried in the patient's mouth. Conclusion: the use of putty material combined with feeding bottle nipple in infants with cleft palate may function as obturator. Furthermore, correction using the one of the modified feeding bottle can be carried out every 1-2 weeks until surgical repair of the cleft palate is performed.
\end{abstract}

Keywords: cleft palate, feeding bottle, putty material, nutrition

\section{INTRODUCTION}

$\mathrm{N}$ mber of patients with cleft lip and palate that need surgical treatment to repair still remains high. Generally, classification of oral clefts includes cleft lip (CL), CL with a cleft palate (CL/CP), and cleft palate alone (CPO). Data showed that $\mathrm{CL} / \mathrm{CP}$ was the most common type (59.8\%) followed by CPO $21.9 \%$ and CL $18.3 \%{ }^{1}$. The prevalence of oral clefts is about 1-2 per 1,000 live births worldwide. The highest prevalence has been reported in Asians, followed by European, and Africans ${ }^{2}$.
Infants born with cleft lip and palate need food intake to improve their nutrition. Naturally, a newborn can suck at breast and latch well to get breast milk, but those with cleft lip and palate have difficulties to press the nipple by their tongues towards palatal direction. Inadequate breast milk intake can lead to weight loss and poor nutrition. Moreover, surgical repair of that cleft lift and palate has requirements of minimum body weight and age. Accordingly, poor nutrition will impair the surgical preparation in patients with cleft lip and palate. Unfortunately, there are difficult to find 
feeding bottle for infants born with cleft lip and palate at the peripheral area.

\section{CASE REPORT}

A 10-day-old female infant came to oral and maxillofacial clinic at Hospital of the University of Brawijaya with complaint of not being able to breastfeed or feed from a normal bottle and accordingly need to use spoon for milk feeding. Patient was planned to perform first operation at 3 months of age. According to clinical examination, patient was presented with cleft lip and cleft palate. During at-home care, nasogastric tube (NGT) had been placed on the patient to facilitate milk intake into the stomach (Figure 1).

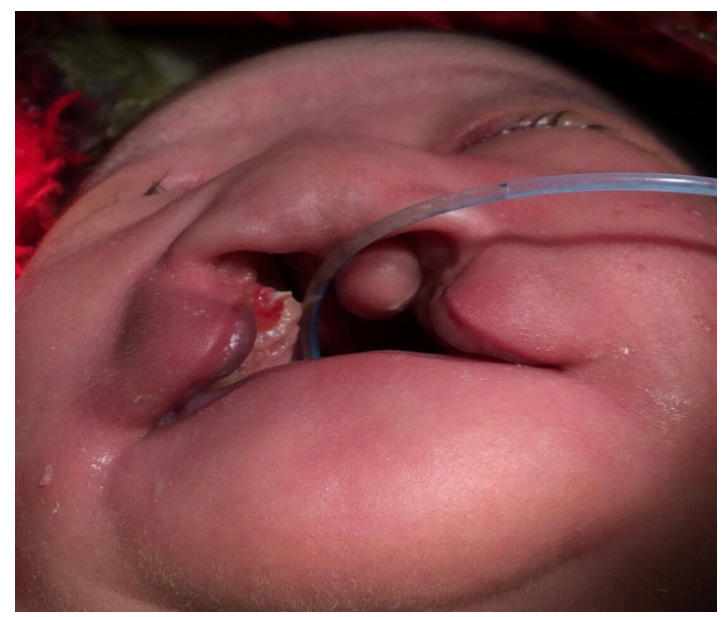

Figure 1. Clinical condition of patient with CLP on nasogastric tube.

At the first visit, impression procedure was performed using red wax material (Figure 2). That material was warmed to obtain more flexible consistency, then it was inserted into oral cavity of the infant and shaped manually by operator's hands according to the defect on infant's palate. Impression making using the red wax material can be repeated 2-3 times to obtain the most accurate cast.

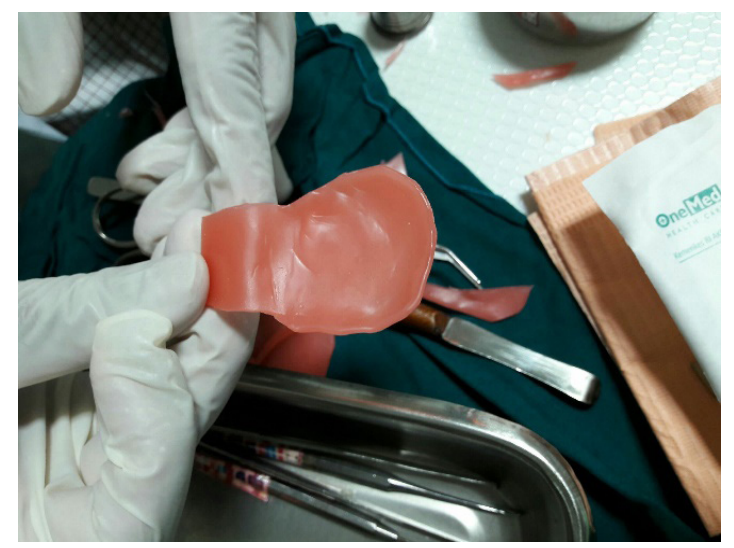

Figure 2. The making of palatal impression using red wax material.
Thereafter, the impression was molded using blue dental plaster (Figure 3). The molding aimed to obtain the cast as a model for fabrication of feeding obturator.

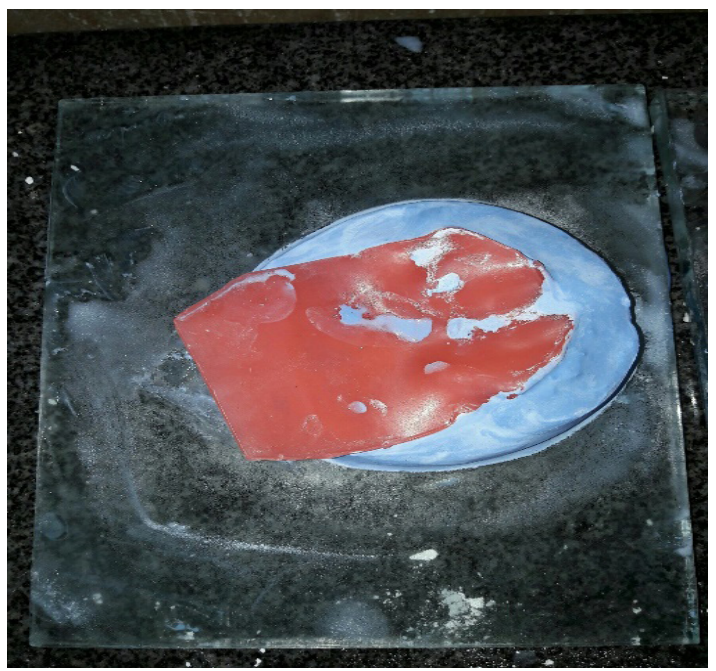

Figure 3. Molding process using blue dental plaster

The resulting cast that made using the blue dental plaster interpreted patient's palate model with cleft. Subsequently, feeding obturator was fabricated using putty impression material or additional silicone, and standard feeding bottle was prepared. The feeding bottle could be found at baby shop. The putty impression material material was prepared to enable to be shaped. Next, the putty impression material was shaped according to the model of cleft that had been molded with blue dental plaster. The nipple of feeding bottle was positioned at occlusal area. Additional silicone was also shaped to fixate the nipple (Figure 4).

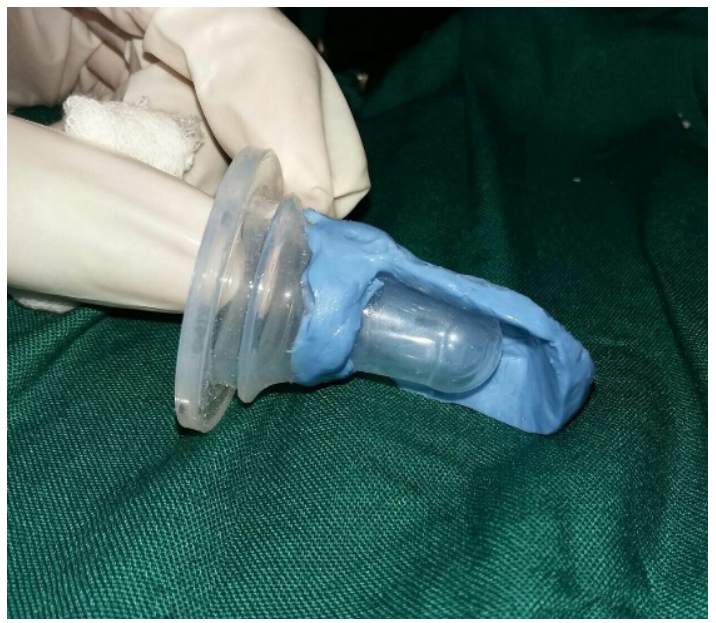

Figure 4. Putty was shaped according to the cast and attached to the nipple.

The nipple of feeding bottle was tried in the patient's mouth afterward, and inspected for any 
excessive putty material, which, if present, was trimmed to obtain the suitable shape. Once the fit was confirmed, it was then assembled back to the body of the bottle and could be used to feed the baby for later (Figure 5).

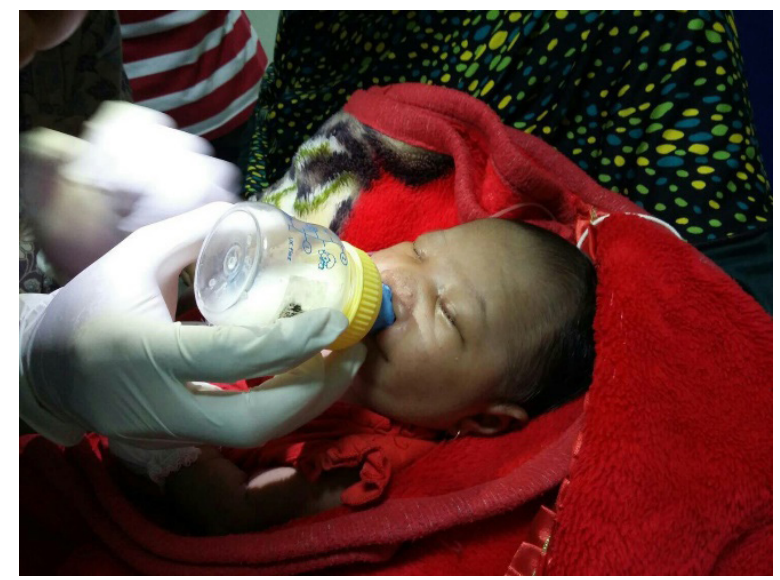

Figure 5. The application of feeding bottle modified with obturator.

\section{DISCUSSION}

Naturally, a newborn can suck at breast and latch well to get breast milk, but those with cleft lip and palate have difficulties to press the nipple by their tongues towards palatal direction. Improper position of the nipple leads to inadequate negative intra-oral pressure which results in insufficient breast milk feeding.

Stages of cleft lip and palate repair consist of lip repair, which is performed in the first three months, and palate repair, which has to be performed by one year of age at the latest or before entering speech phase. Cleft lip repair may be performed at 4-6 months of age, following the "rule of ten" as a standard requirements i.e. 10 pounds of body weight, 10 weeks old and $10 \mathrm{mg} / \mathrm{dl}$ of haemoglobin. Cleft palate repair may be performed at 9-15 months of age just before speech skill starts to develop ${ }^{3}$.

Patients with cleft lip and palate are very prone to malnutrition. Their nutrient intake is inadequate because they are not able to create the suction needed to pull milk out of the baby bottle or to latch on to the breast to breastfeed. The appropriate method to feed those with cleft lip and palate is by placing the baby in an upright position to prevent choking and the milk from flowing back into the respiratory passage. In addition, the recommended frequency of feeding is at least 8 to 12 times in 24 hours $^{4}$.

Inadequate breast milk intake can lead to weight loss and poor nutrition. Moreover, surgical repair of that cleft lip and palate has requirements of minimum body weight and age. Accordingly, poor nutrition will impair the surgical preparation in patients with cleft lip and palate.
Specifically designed and manufactured feeding bottle for patient with CLP is commercially available and sold in stores. However, in some regions this kind of bottle is not available. Therefore, modification of standard feeding bottle is needed to enable patient to be fed. A variety of modification has been made regarding cleft disorders, one of them is modified feeding bottle with spoon ${ }^{5}$. Some methods of feeding that enable nutrient intake for infants with cleft lip or cleft palate include suction method with feeding bottle; nasogastric tube (NGT); or dropper to drip feed into the infant's mouth.

The use of feeding bottle in infants with cleft lip or cleft palate may assist to improve nutrient intake optimally. However, patient should not use bottle (suction method) for nutrient intake in the postoperative period of palate repair surgery because of the risk of postoperative complications, such as bleeding or suture detachment of palatal flap ${ }^{6}$.

The use of this modified feeding bottle with obturator needs to be revised several times, thus it is not completely done in one time making process. The jaw bone that is continually developing causes the size change of cleft palate defect. The revision of obturator should be done at least every 1-2 weeks. Modified feeding bottle use may provide sufficient negative pressure in oral cavity which leads to adequate suction and swallowing processes.

Additional silicone (putty) material that used as obturator on the feeding bottle has favorable qualities as dimensional accuracy and stability for one week period $^{7,8}$. Accordingly, impression procedure needs to be done again after one week period. Even though functionally the obturator can still be used after seven days, but the damage of putty material may cause porous formation which potentially become the place of bacterial accumulation

Early cleft palate closure should be performed on soft palate first, while correction on hard palate is mucosal closure without involving alveolar bone. It aims to improve patient's nutrient intake and speech function. Moreover, surgical correction of the bone may be performed after pubertal peak velocity age to obtain more favorable effect ${ }^{9}$. Early palatoplasty produces inhibition on the growth of the maxilla and the surgical region has been shown to grow more slowly than the surrounding tissue ${ }^{10}$.

Key points that should be informed to the parents of patient with cleft lip and palate during use of modified feeding bottle, as follows: the appropriate position of feeding bottle to prevent choking; frequency of feeding is at least 8 to 12 times in 24 hours; To summarize, apart from the proper feeding positions, these following instructions should also be given to the parents; burping more often, 2 to 3 times during feed; oral hygiene maintenance, especially on gum and obturator prosthesis; sterilization of feeding 
bottles and nipples. Administration of nutrition using modified feeding bottle will provide adequate effect of nutrient intake because it enables infants to do optimal milk suction.

\section{CONCLUSION}

Modified feeding bottle that we created is convenient regarding material preparation, because putty impression materials are easy to find, and almost all dentists have it. Good stability characteristic of putty material may enable infants to adapt during feeding. Furthermore, the bottle used here is standard feeding bottle that is available and easy to find in the market.

\section{REFERENCES}

1. R. Ittiwut, P. Siriwan, K. Suphapeetiporn and V. Shotelersuk, "Epidemiology of Cleft lip with or without cleft palate in Thais," Asian Biomedicine, vol. 10, no. 4, pp. 335-338, August 2016.

2. S. E. Watkins, R. E. Meyer, R. P. Strauss and A. S. Aylsworth, "Classification, epidemiology, and Genetics of Orofacial Clefts," Clinics in Plastic Surgery, vol. 41, no. 2, pp. 149-163, April 2014.

3. K. Kobus and K. K. Zalesna, "Timing of Cleft Lip and Palate Repair," Developmental Period Medicine, vol. 18, no. 1, pp. 79-83, 2014.
4. M. K. Jindal and S. Y. Khan, "How to Feed Cleft Patient," International Journal of Clinical Pediatric Dentistry, vol. 6, no. 2, pp. 100-103, May-August 2013.

5. V. S. Hiremath, A. B. Lingegowda, S. Rayannavar and N. Kumari, "A Innovative Technique - Modified Feeding Bottle for a Cleft Palate Infant," Journal of Clinical and Diagnostic Research, vol. 10, no. 4, April 2016.

6. G. A. Duarte, R. B. Ramos and M. C. Cardoso, "Feeding methods for children with cleft lip and/ or palate : a systematic revew," Brazilian Journal of Otorhinolaryngology, vol. 82, no. 5, pp. 602-609, 2016.

7. R. Mehta, S. Wadhwa, N. Duggal, A. Kumar and M. Goel, "Influence of Repeat Pours of Addition Silicone Impression on theDimensional Accuracy of Cast," Journal of Interdisciplinary Medicine and Dental Science, vol. 2, no. 1, 2014.

8. S. Rathee, B. Eswaran, M. Eswaran, R. Prabhu, K. Geetha, G. Krishna and Jagadeshwari, "A Comparison of Dimensional Accuracy of Additional Silicone of Different Consistencies with Two Different Spacer Design - In vitro Study," Journal of Clinical and Diagnostic Research, vol. 8, no. 7, pp. 38-41, Jul 2014.

9. Y. F. Liao and M. Mars, "Hard Palate Repair Timing and Facial Morphology in Unilateral Cleft Lip and Palate : Before versus After Pubertal Peak Velocity Age," Cleft Palate-Craniofacial Journal, vol. 43, no. 3, May 2006.

10. B. Shi and J. E. Losee, "The impact of cleft lip and palate repair on maxillofacial growth," International Journal of Oral Science, vol. 7, pp. 14-17, 2015. 